
ADHESIVE
VAPOR
HEPTANES
ISOMERS
EXPOSURE
INDOOR
SAMPLING
GC - MS
WORLD CHAMPIONSHIPS

Open access manuscript version of

Toxicological and Environmental Chemistry 47 (1995) 1-6

Link to publisher

\title{
Ambient solvent hydrocarbons from the gluing of table tennis bats
}

Olle Ramnäs, Gunnar Barrefors and Göran Petersson

Branched saturated vapor hydrocarbons also characterize gasoline based on alkylate 


\title{
Ambient Solvent Hydrocarbons from the Gluing of Table Tennis Bats
}

\author{
Olle Ramnäs, Gunnar Barrefors and Göran Petersson* \\ Department of Chemical Environmental Science \\ Chalmers University of Technology \\ 41296 Göteborg \\ Sweden
}

\begin{abstract}
Solvent hydrocarbons released to air from the controversial but widely applied gluing of table tennis bats were studied during the 1993 world championships in Göteborg. Sampling on adsorbent cartridges and thermal desorption combined with gas chromatography and mass spectrometry were used for the determinations.

The total concentrations recorded above the players' gluing tables were in the range 20$100 \mathrm{mg} \mathrm{m}^{-3}$. The prominent solvent constituents were $\mathrm{C}_{6}(<10 \%), \mathrm{C}_{7}(>80 \%)$, and $\mathrm{C}_{8}$ $(<5 \%)$ alkanes and cycloalkanes. The proportions of the nine acyclic and the seven cyclic $\mathrm{C}_{7}$ isomers were determined. Heptane, 2-methylhexane and 3-methylhexane constituted more than $50 \%$ of the solvent hydrocarbons.
\end{abstract}

\section{INTRODUCTION}

The solvents used for gluing the gum sheets onto the table tennis bats before matches have been an issue of increasing concern within the sport for some time. At the world championships in Göteborg certain solvents were banned, and a complete ban on organic solvents is scheduled for the near future. This issue may be of wide interest because similar changes may be foreseen for other uses of organic solvents. The ambient hydrocarbons reported here from the Göteborg event represent solvents hitherto thought to minimize solvent health effects. 


\section{EXPERIMENTAL}

The gluing procedure. Samples were taken during one of the first days of the men's single tournament with many players in action. Gluing was performed at three tables screened off in a large hall. The available space allowed 3-6 players at a time to glue their bats. The players brought their own cans with authorised glue makes. Glue was applied to both sides of the bat and to the gum sheets which were subsequently affixed to the bat. Normally, 1020 minutes were used for the procedure.

Sampling. Triple-layer adsorbent tubes (glass, $150 \mathrm{~mm} \times 4 \mathrm{~mm}$ i.d.) with Tenax TA, Carbotrap and Carbosieve S-III were used for sampling of all non-methane hydrocarbons as previously described (Barrefors and Petersson, 1993). Control samples on single-layer Tenax TA cartridges permitted quantitative determination of all $\mathrm{C}_{6}$ and higher hydrocarbons. The adsorbent cartridges were coupled to conventional portable air pumps permitting accurate determination of sampling volumes. The pumps were placed on a wall shelf with the adsorbent tubes hanging $1.5 \mathrm{~m}$ above the gluing tables.

Sampling was arranged as two parallel long-time samples (100 min, 247 and $979 \mathrm{ml}$ ) and four duplicate short-time samples (10-30 min, 200-500 ml) taken during the long-time sampling period.

Laboratory analysis. One of the duplicate samples was used for GC and the other for GCMS on recently described analytical systems (Barrefors and Petersson, 1993).

The GC system for group separation of hydrocarbons and quantitative FID determinations is based on thermal desorption, cryo-focusing and separations on an $\mathrm{Al}_{2} \mathrm{O}_{3} / \mathrm{KCl}$ column (Chrompack, $50 \mathrm{~m} \times 0.32 \mathrm{~mm}$ i.d., fused silica PLOT). The temperature program used in this study was $30-110^{\circ} \mathrm{C}\left(10^{\circ} \mathrm{C} \mathrm{min}^{-1}\right), 110^{\circ} \mathrm{C}$ (isothermal, $\left.14 \mathrm{~min}\right), 110-200^{\circ} \mathrm{C}\left(4^{\circ} \mathrm{C}\right.$ $\min ^{-1}$ ) and $200^{\circ} \mathrm{C}$ (isothermal).

The GC-MS studies were performed on a Varian Saturn II ion trap instrument. The compounds were thermally desorbed, cryo-focused and analysed on a DB-1 methylsilicone column (FSOT, $50 \mathrm{~m} \times 0.32 \mathrm{~mm}$ i.d., $1 \mu \mathrm{m}$ phase layer). The column temperature was increased by $2{ }^{\circ} \mathrm{C} \mathrm{min}^{-1}$ from below $0{ }^{\circ} \mathrm{C}$, and the prominent solvent compounds appeared in the temperature range 50-70 ${ }^{\circ} \mathrm{C}$. Single-ion monitoring and comparisons with data-stored library spectra aided the identifications.

\section{RESULTS AND DISCUSSION}

Hydrocarbons from gluing. In Table I, the proportions of hydrocarbon classes are given for one long-time and one short-time sample. The acyclic and cyclic $\mathrm{C}_{7}$ alkanes constituted more than $80 \%$ of the solvent hydrocarbons in the ambient air. The remainder was essentially $\mathrm{C}_{6}$ and $\mathrm{C}_{8}$ alkanes. Three additional short-time samples, taken during the long sampling period, gave very similar proportions. The proportion of methylbenzene was 
Table I Ambient hydrocarbons above the tables used for gluing by the players.

\begin{tabular}{lcccc}
\hline & \multicolumn{2}{c}{$19 \mathrm{May}, 11.40-13.20^{2}$} & \multicolumn{2}{c}{$19 \mathrm{May}^{2}, 13.20-13.35$} \\
& $\mathrm{mg} \mathrm{m}^{-3}$ & $\%$ & $\mathrm{mg} \mathrm{m}^{-3}$ & $\%$ \\
\hline C5 Pentanes & 0.6 & 0.8 & 0.6 & 1.9 \\
C6 Hexanes & 6.8 & 8.9 & 2.9 & 9.7 \\
C7 Heptanes & 64.0 & 83.4 & 24.6 & 80.8 \\
C8 Octanes & 3.7 & 4.9 & 1.3 & 4.2 \\
C9 Nonanes & 0.5 & 0.7 & 0.4 & 1.3 \\
C7 Methylbenzene & 0.6 & 0.8 & 0.4 & 1.3 \\
\hline
\end{tabular}

0.5-1.0\% for all but the tabulated short-time sample. The total concentration of solvent hydrocarbons was within the range $20-100 \mathrm{mg} \mathrm{m}^{-3}$ for all samples. The long-time sample should be best representative because about 40 players glued their bats during the sampling time.

The proportions of the different hydrocarbon classes were most favourably determined on the aluminium oxide column. This is illustrated in Figure 1 by the chromatogram for the tabulated short-time sample. The alkanes are clearly separated according to carbon number with the $n$-alkanes appearing last within each group. Alkenes appear between the alkane groups on the aluminium oxide column (Barrefors and Petersson, 1993) and are seen to be almost absent. The proportion of heptenes was about $0.1 \%$ and that of hexenes even less, as observed from chromatograms recorded with a lower attenuation. The small amounts observed for benzene and dimethylbenzenes (xylenes) may be due to traffic emissions. The concentrations are of the same order, $0.05 \mathrm{mg} \mathrm{m}^{-3}$, as those observed inside cars in urban traffic (Barrefors and Petersson, 1993). Sources other than glue solvents may also contribute non-negligibly to methylbenzene and pentanes.

Heptanes and cycloheptanes. For the separation of alkane and cycloalkane isomers, nonpolar methylsilicone columns perform better than the alumina column. In Figure 2, the total ion chromatogram from GC-MS analysis of the duplicate long-time sample is reproduced. The heptane and cycloheptane isomers appear in the chromatographic range between hexane and octane on the methylsilicone column. Calibration checks for the ion trap instrument indicated a similar response for all $\mathrm{C}_{7}$ alkanes and cycloalkanes, but a lower response for $\mathrm{C}_{6}$ and a higher response for $\mathrm{C}_{8}$ alkanes and cycloalkanes within the approximate range $+/-20 \%$.

The predominant $\mathrm{C}_{7}$ saturated hydrocarbons were studied in some detail. In Table $I$, the observed proportions are given for the nine isomers of acyclic heptanes $(86 \%)$ and the seven isomers of cycloheptanes (14\%). Heptane, 2-methylhexane and 3-methylhexane were the most prominent (69\%) species. Incompletely resolved isomers were identified and 
Table II Ambient heptanes emitted from the gluing of table tennis bats.

\begin{tabular}{lrcc}
\hline & $\begin{array}{c}\text { Proportions } \\
\text { of heptanes } \\
\text { w/w } \%\end{array}$ & $\begin{array}{c}\text { Rel. retention } \\
\text { methylsilicone } \\
\text { MU }\end{array}$ & $\begin{array}{c}\text { Boiling point } \\
\text { reference data } \\
{ }^{\circ} \mathrm{C}\end{array}$ \\
\hline Acyclic heptanes & \multicolumn{1}{c}{86} & & \\
2,2-Dimethylpentane & 1 & 6.24 & 79.2 \\
2,4-Dimethylpentane & 3 & 6.30 & 80.5 \\
2,2,3-Trimethylbutane & 0 & 6.34 & 80.9 \\
3,3-Dimethylpentane & 2 & 6.53 & 86.0 \\
2-Methylhexane & 22 & 6.68 & 90.0 \\
2,3-Dimethylpentane & 8 & 6.70 & 89.8 \\
3-Methylhexane & 25 & 6.76 & 91.8 \\
3-Ethylpentane & 3 & 6.86 & 93.5 \\
Heptane & 22 & 7.00 & 98.4 \\
Cycloheptanes & 14 & & \\
1,1-Dimethylcyclopentane & 0 & 6.71 & 87.8 \\
cis-1,3-Dimethylcyclopentane & 2 & 6.81 & 90.8 \\
trans-1,3-Dimethylcyclopentane & 1 & 6.84 & 91.7 \\
trans-1,2-Dimethylcyclopentane & 2 & 6.87 & 91.9 \\
cis-1,2-Dimethylcyclopentane & 2 & 7.20 & 99.5 \\
Methylcyclohexane & 5 & 7.20 & 100.9 \\
Ethylcyclopentane & 2 & 7.32 & 103.5 \\
\hline
\end{tabular}

determined by interpretation of mass spectra, by single-ion monitoring and by retention data. Relative retentions are given as methylene units (MU) on the methylsilicone column, indicating chromatographic positions relative to the $n$-alkanes. The retention order on the non-polar column nearly follows the order of increasing boiling points. The major hydrocarbons are in the boiling point range $85-105^{\circ} \mathrm{C}$. Retention data of a wide range of hydrocarbons on methylsilicone columns are available for comparisons (White et al., 1992).

Health hazards. Chlorohydrocarbons and alkylbenzenes are common volatile solvent components linked to particular health hazards. Therefore, the four representative compounds trichloroethene, toluene (methylbenzene), ethylbenzene and xylene (dimethylbenzenes) were banned as glue solvents by the International Table Tennis Federation (ITTF). At the world championships, the compliance of the ban was officially checked by Dräger tests on these air pollutants for randomly selected glued bats placed in test boxes. When needed, control samples for GC and GC-MS confirmations were taken on carbon cartridges. These official tests as well as the results in this report demonstrated 
that almost no abuse of the banned solvents occurred.

The results given demonstrate a complex composition of the predominant heptane fraction. Specific health effects of individual hydrocarbons cannot be excluded. Hexane is a related unbranched hydrocarbon with a known neurotoxic effect (Perbellini et al., 1980). Its proportion was below $2 \%$ because of the higher boiling point range of the heptanes. As demonstrated for 3-methylheptane in rats (Serve et al., 1993), alkanes occurring in solvents give rise to a wide variety of metabolites. Certain resulting carboxylic acids are peroxisome proliferaters linked to enzyme induction and possibly liver cancer.

The reported major glue solvent components may give rise to general short-time physiological solvent effects. These include potentially lowered reaction rate and coordination ability which may be important for the performance of the players involved. The most important long-time health hazards are likely to be linked to the increased formation of free oxygen radicals from the metabolism of hydrocarbons. These radicals are thought to increase the ageing of the cell, the incidence of cancer, and the development of autoimmune and several other physiological defects. For sportsmen, the effect of hydrocarbons adds to an increased radical formation due to a high oxygen intake. It is concluded that prohibition of the use of organic solvents in sports is essential both to the numerous young sportsmen and as a good example in other fields of solvent use.

ACKNOWLEDGEMENT: The authors thank Dr Paul Schilz from the Equipment Committee of the International Table Tennis Federation for valuable cooperation and discussions.

\section{REFERENCES}

Barrefors G. and Petersson G. (1993). Assessment of ambient volatile hydrocarbons from tobacco smoke and from vehicle emissions. J. Chromatogr., 643, 71-76.

Perbellini L., Brugnone F. and Pavan I. (1980). Identification of the metabolites of $\mathrm{n}$-hexane, cyclohexane, and their isomeres in men's urine. Toxicol. Appl. Pharmacol., 53, 220-229.

Serve M. P., Bombick D. D., Clemens J. M., McDonald G. A., Hixson C. J. and Mattie D. R. (1993). The metabolism of 3-methylheptane in male 344 Fischer rats. Chemosphere, 26, 1667-1677.

White C. M., Hackett J., Anderson R. R., Kail S. and Spock P. S. (1992). Linear temperature programmed retention indices of gasoline range hydrocarbons and chlorinated hydrocarbons on cross-linked polydimethylsiloxane. J. High Resolut. Chromatogr., 15, 105-120. 